\title{
Continental Transform Boundaries: Tectonic Evolution and Geohazards
}

\author{
by Cecilia M.G. McHugh, Leonardo Seeber, M. Namik Çağatay, Pierre Henry, \\ Christopher Sorlien, Michael Steckler, and Gülsen Uçarkuş
}

doi:10.2204/iodp.sd.13.11.2011

\section{Introduction}

Continental transform boundaries cross heavily populated regions, and they are associated with destructive earthquakes, for example, the North Anatolian Fault (NAF) across Turkey, the Enriquillo-Plantain Garden fault in Haiti, the San Andreas Fault in California, and the El Pilar fault in Venezuela. Transform basins are important because they are typically associated with 3-D fault geometries controlling segmentation - thus, the size and timing of damaging earthquakes-and because sediments record both deformation and earthquakes. Even though transform basins have been extensively studied, their evolution remains controversial because we don't understand the specifics about coupling of vertical and horizontal motions and about the basins' long-term kinematics. Seismic and tsunami hazard assessments require knowing architecture and kinematics of faults as well as how the faults are segmented.

A four-day workshop, 13-16 June 2011 at Istanbul Technical University, Istanbul, Turkey, focused on the seismo-tectonic evolution of the Marmara Sea, which is $150 \mathrm{~km}$ long and includes three 1200 -m-deep subsiding basins (Figs. 1, 2). The submerged Marmara segment of the NAF is considered a seismic gap presenting high risk to Istanbul and its surroundings. The workshop was sponsored by the Integrated Ocean Drilling Program (IODP) to lay the groundwork for a proposal in the Marmara Sea.

The NAF extends east-west for over $1600 \mathrm{~km}$ across Turkey (Fig. 1). The northern branch of the NAF crosses the Marmara Sea and now accommodates most of the 21-25 $\mathrm{mm} \mathrm{y}^{-1}$ motion between the Anatolian block and the Eurasian plate (Reilinger et al., 2010). Since 1939, a sequence of seven $\mathrm{M}>7$ earthquakes ruptured the NAF progressively westward across Turkey but to the east of Marmara Sea. The most recent two in 1999 were just east of the sea and particularly destructive ( 17,000 deaths). West of the Marmara Sea an $\mathrm{M}_{\mathrm{w}} 7.4$ earthquake ruptured the NAF's Ganos segment in 1912. The only unruptured segments of the NAF in the last century are within the Marmara Sea. They have been identified as a seismic gap with as much accumulated elastic strain as was released in the 1999 sequence (Parsons, 2004).

Details regarding the fault system beneath the Marmara Sea are challenging traditional models for transform tectonics. Some authors account for structural complex-

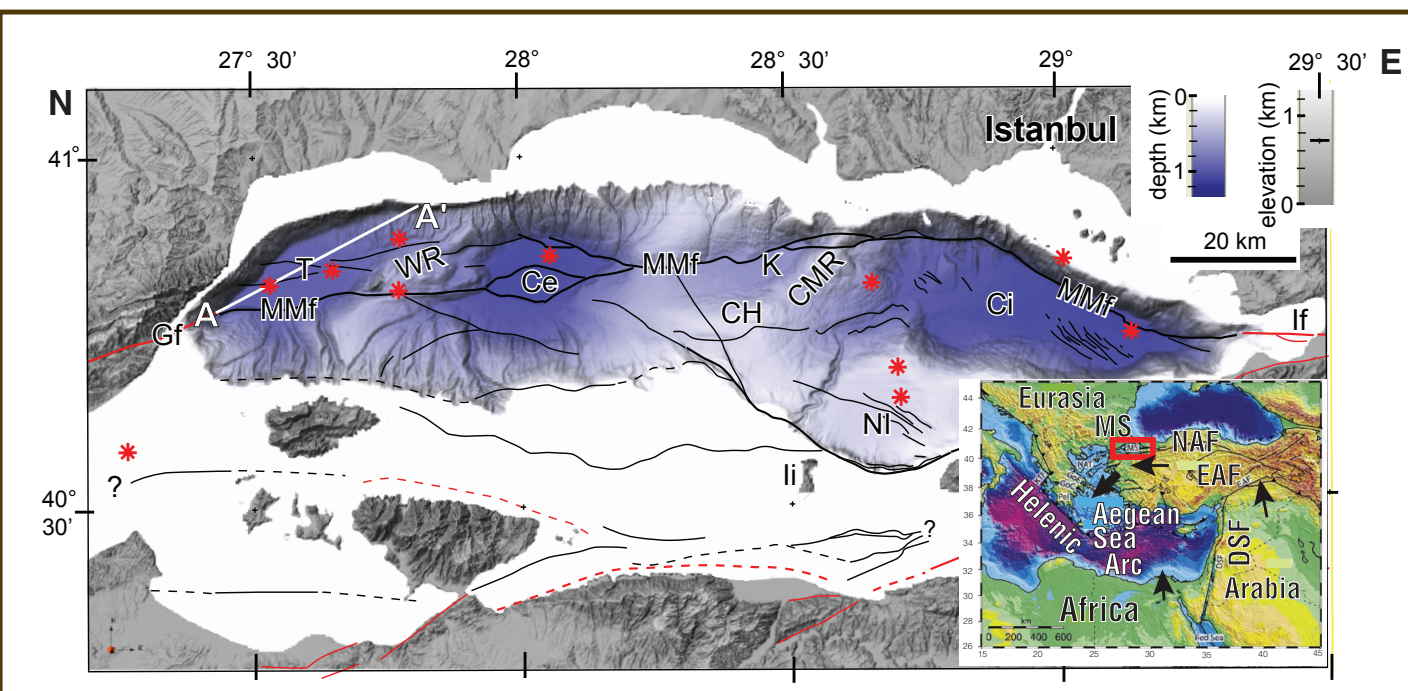

Figure 1. Bathymetry and topography of the Marmara Sea region (bathymetric data from Rangin et al., 2001) showing its basins from east to west: Cinarcik (Ci), North Imrali (NI), Kumburgaz (K), Central (Ce), Tekirdag (T). These basins are separated by the Central Marmara Ridge (CMR) and Western Ridge (WR). The main faults are shown as black lines (Sorlien et al., 2012); those in red are from several published sources as explained in Sorlien et al. (2012): Izmit fault (If), Main Marmara fault (MMf), and Ganos fault (Gf). The red stars mark the locations of the proposed drill sites. Inset shows the topography of the eastern Mediterranean with plate tectonic configuration and GPS-derived vectors (Reilinger et al., 2010). Red box locates Marmara Sea. Also shown are the North Anatolia Fault (NAF), East Anatolia Fault (EAF) and Dead Sea Fault (DSF). ities and basins as relics and propose throughgoing transcurrent faults in the current regime (Le Pichon et al., 2001). Alternatively, basins may grow in a steady-state regime. Crustal thinning and subsidence may stem from pull-apart fault geometries and strain partitioning (Armijo et al., 2005) or from oblique slip on non-vertical throughgoing master faults (Okay et al., 2000; Seeber et al., 2006). Particulars of these models determine the segmenta- 
tion of the gap and the size and number of future earthquakes and the hazard facing Istanbul.

Other large metropolitan regions are threatened by continental transforms. This workshop was held to discuss the research opportunities presented by drilling in the Marmara Sea.

\section{Scientific Presentations}

Forty scientists and fifteen graduate and undergraduate students from Europe, Turkey, and the USA attended the IODP Marmara-Trans workshop. The presentations covered the evolution of the plate boundary from subduction to strike slip. Thermal models of the Marmara Sea basins focused on whether the growth was steady, or whether the basins grew initially and passively rode along the transform later. Structural evidence suggests asymmetric fault-bend basins subsiding steadily into the present (Seeber et al., 2004). Unconformities were identified, tentatively dated, and correlated in all the Marmara Sea basins from seismic profiles (Sorlien et al., 2012). Constraining the age model would be critical for evaluating the basins' structural evolution. Large earthquakes and tsunamis have been known for 2000 years from the historical record, and into the upper Holocene from the geological record. Historical and geological data overlap and correlate. Earthquake-triggered deep-water sedimentation in Haiti and Marmara Sea are remarkably similar. They suggest "turbidite-homogenite" units with characteristic structures and chemistry (McHugh et al., 2006; Beck et al., 2007) that could be recognized in the stratigraphy and provide an earthquake record through the growth of the basin. Better understanding of how seismogenesis relates to other geologic observables would improve earthquake forecasting and hazard assessment along the North Anatolian Fault and other continental transforms.

Reconnections between the Black, Marmara, and Aegean Seas in response to eustasy and climate have been much debated in recent years. These freshwater and saltwater exchanges were accompanied by dramatic transitions in flora, fauna, and geochemistry that have been recorded in the sediments of Marmara Sea. But, available piston and gravity cores extend back for only 130 ka (Çağatay et al., 2009). A longer sedimentary record would recover repeated eustatic and climate cycles and thus distinguish the role of tectonics from sea-level fluctuations.

Seafloor gas emissions and fluid expulsions, observed with ROV and manned submersibles, appear to be focused along active faults in the Marmara Sea (Zitter et al., 2008; Géli et al., 2008). Surveys based on multichannel seismic reflection profiles, chirp, and multibeam data found a widespread distribution of gas in the sediment and the strongest gas discharge in the water column above the topographic highs between basins (Shillington et al., in press). Conduits along the main transform on the Western High expel thermogenic gas and associated brines. 3-D high-resolution seismic data in the same area document the interplay of sediment deformation and formation of fluid conduits (Bourry et al., 2009; Tryon et al., 2010). Authigenic carbonates and associated biogeochemical communities were recently discovered in Marmara Sea. These findings reveal that hydrological and biogeochemical activities along continental transforms are as intense as in other plate boundaries.

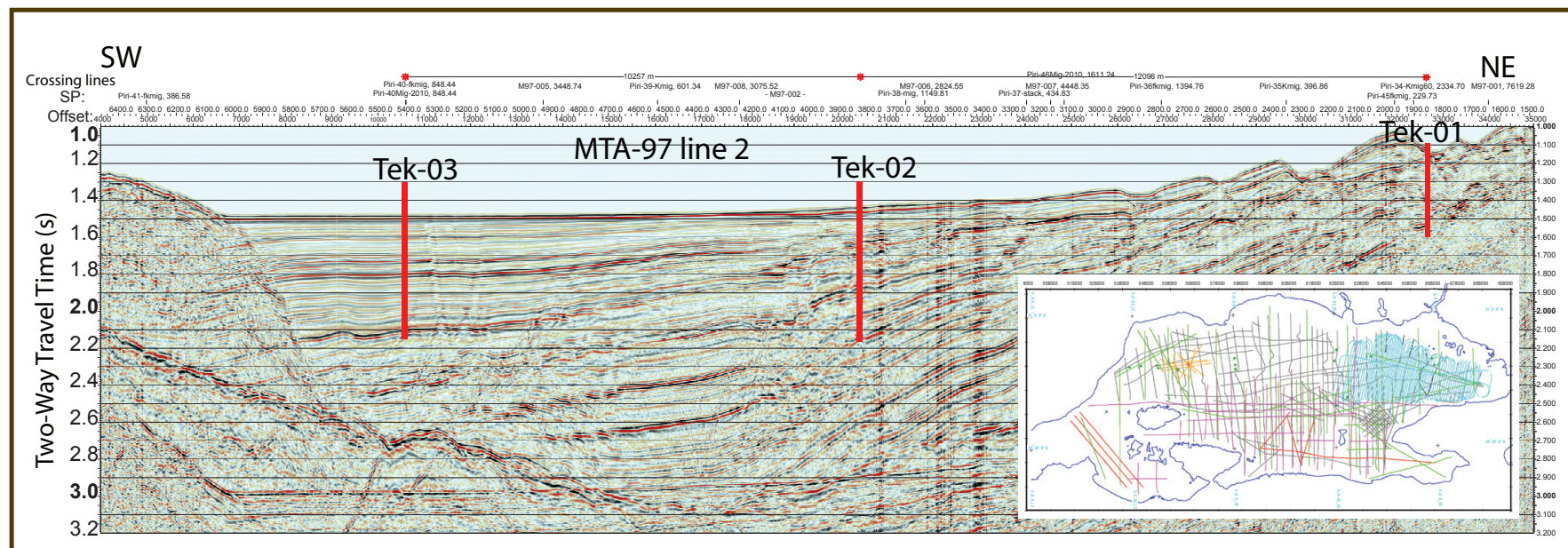

Figure 2. Multichannel seismic reflection (MCS) line MTA97 line 2 across Tekirdag Basin (white A-A' line on Fig. 1; data from Parke et al., 2003). The red rectangles show the locations of potential drilling sites. Tek-03: this SW location was targeted to reach Pleistocene to Holocene strata deposited at high sedimentation rates at the deepest part of the basin (1200 m of water depth). Tek-02 (projected $2.7 \mathrm{~km}$ from the SE): targeted to reach Pliocene to Pleistocene strata. Tek-01 (projected $2.6 \mathrm{~km}$ from the SE): targeted at the condensed margin of the basin to reach Miocene to Holocene strata.

Inset showing available high-resolution MCS data. Gray lines: TAMAM-2008 and PirMarmara Leg a4 (Sorlien et al., 2012). Orange lines are PirMarmara 2010 Leg a2 (P. Henry, G. Çifçi, and others, unpublished). Red lines are PirMarmara 2010 Legs a1, a3 (G. Çifçi and others, unpublished). The dense cyan grids are from Carton et al., 2007. Magneta are Marathon industry lines (C\&K Petroleum, 1974). Green lines are from MTA97 (Parke et al., 2003). 


\section{Links to Other Programs}

Several seafloor observatories, which monitor seismic hazards long-term, and continental drilling programs are being carried out in Marmara Sea and surroundings by Turkey and international groups. Observatories have been deployed in Marmara Sea for understanding the long-term relationship between fluids and seismicity as part of the Marmara Demonstration Mission project funded by the European Seafloor Observatory Network and the European Multidisciplinary Seafloor Observatory. The International Continental Scientific Drilling Program (ICDP) project GONAF (a deep Geophysical Observatory at the North Anatolian Fault) plans to drill two boreholes in the Princes Islands, Turkey. Representatives of this program presented their preliminary results on seismotectonics. Future programs include the development and implementation of submarine geodetics as part of seismic risk assessment in collaboration with Istanbul Technical University and the Turkish Navy. Deployment of seafloor drilling rig MeBo is also being considered to investigate the interactions between sediment deformation and fluids.

\section{Outcome of the Workshop}

The working group participants selected locations for drilling sites based on existing data. These were recorded from geophysical investigations (multichannel seismic reflection profiles, multibeam bathymetry, high-resolution sub-bottom profiles, side scan sonar), sediment sampling (piston cores up to $30 \mathrm{~m}$ long and many gravity cores), and explorations by manned and unmanned submersibles. The data were acquired during the following cruises and research vessels: Seismarmara, Marmarascarps, Marnaut, Marmesonet, R/V Marion Dufresene, R/V Urania (2002, 2009), and R/V Piri Reis (project TAMAM: 2008, 2010) (Rangin et al., 2001; Le Pichon et al., 2001; Polonia et al., 2004; Armijo et al., 2005; Cormier et al., 2006; Steckler et al., 2008; Géli et al., 2008; Görür and Çağatay, 2010).

These proposed drilling sites target the main Marmara Sea basins with the following goals.

1. Their deepest parts are intended to recover an expanded Holocene to Pleistocene strata with high sedimentation rates.

2. The condensed margins of the basins could reach older, possibly Miocene, strata.

3. They are located at and near fluid emission sites within the main fault zone to characterize the nature of the conduits and the timing of past activity, and to install borehole monitoring systems for fluid pressure and chemistry.
4. Additional plans for borehole instrumentation include monitoring of strain rates and seismic activity. These objectives would address major issues, such as the partitioning between fluid from deep sources possibly relevant to earthquakes and fluid from the compaction and dewatering of sediments.

These scientific and drilling objectives target the new International Ocean Discovery Program focusing on the "Earth's driving tectonics which reveal its inner workings and cause major geological hazards”.

\section{Acknowledgments}

We thank IODP-MI, the Eastern Mediterranean Centre for Oceanography and Limnology, and Queens College, City University of New York for their support.

\section{References}

Armijo, R., Pondard, N., Meyer, B., Uçarkus, G., Mercier de Lepinay, B., Malavieille, J., Dominguez, S., et al., 2005. Submarine fault scarps in the Sea of Marmara pull-apart (North Anatolian Fault): Implications for seismic hazard in Istanbul. Geochem. Geophys. Geosys., 6:Q06009. doi:10.1029/2004GC000896

Beck, C., de Lepinay, M., Schneider, J.-L., Cremer, M., Çağatay, N., Wendenbaum, E., Boutareaud, S., Mynot, G., Schmidt, S., and Weber, O., 2007. Late Quaternary co-seismic sedimentation in the Sea of Marmara's deep basins. Sed. Geol., 199:65-89. doi:10.1016/j.sedgeo.2005.12.031

Bourry, C., Chazallon, B., Charlou, J.-L., Donval, J.P., Ruffine, L., Henry, P., Géli, L., Çağatay, M.N., Sedat, İ., and Moreau, M., 2009. Free gas and gas hydrates from the Sea of Marmara, Turkey: Chemical and structural characterization. Chem. Geol., 264:197-206. doi:10.1016/j.chemgeo.2009.03.007

C\&K Petroleum, 1974. Report covering geophysics-geology Marmara offshore, Turkey, $71 \mathrm{pp}$.

Çağatay, M.N., Eriş, K., Ryan, W.B.F., Sancar, Ü., Polonia, A., Akçer, S., Biltekin, D., et al., 2009. Late Pleistocene-Holocene evolution of the northern shelf of the Sea of Marmara. Mar. Geol., 265:87-100. doi:10.1016/j.margeo.2009.06.011

Carton, H., Singh, S.C., Hirn, A., Bazin, S., de Voogd, B., Vigner, A., Ricolleau, A., Cetin, S., Ocakoglu, N., Karakoc, F., and Sevilgen, V.,2007."Seismicimaging of the three-dimensional architecture of the Cinarcik Basin along the North Anatolian Fault. J. Geophys. Res., 112:B06101, doi:10.1029/2006 JB004548.

Cormier, M.-H., Seeber, L., McHugh, C.M.G., Polonia, A., Çağatay, M.N., Emre, Ö., Gasperini, L., et al., 2006. North Anatolian fault in the Gulf of Izmit (Turkey): Rapid vertical motion in response to minor bends of a nonvertical continental transform. J. Geophys. Res., 111:B04102. doi:1029/2005JB003633

Géli, L., Henry, P., Andre, C., Zitter, T., Çağatay, M.N., Mercier de Lepinay, B., Le Pichon, X., et al., 2008. Gas emissions and active tectonics within the submerged section of the North Anatolia Fault zone in the Sea of Marmara. Earth Planet. 
Sci. Lett., 274(1-2):34-39.

Görür, N., and Çağatay, M.N., 2010. Geohazards rooted from the northern margin of the Sea of Marmara since the late Pleistocene: A review of recent results. Nat. Hazards, 54(2):583-603. doi:10.1007/s11069-009-9469-x

Le Pichon, X., Sengör, A.M.C., Demirbag, E., Rangin, C., Imren, C., Armijo, R., Görür, N., et al., 2001. The active main Marmara fault. Earth Planet. Sci. Lett., 192:595-616.

McHugh, C.M.G., Seeber, L., Cormier, M.-H., Dutton, J., Çağatay, M.N., Polonia, A., Ryan, W.B.F., and Görür, N., 2006. Submarine earthquake geology along the North Anatolian Fault in the Marmara Sea, Turkey: A model for transform basin sedimentation. Earth Planet. Sci. Lett., 248:661-684. doi:10.1016/j.epsl.2006.05.038

Okay, A.I., Kaslilar-Ozcan, A., Imren, C., Boztepe-Guney, A., Demirbag, E., and Kuscu, I., 2000. Active faults and evolving strike-slip fault basins in the Marmara Sea, northwest Turkey: A multichannel reflection study. Tectonophysics, 321:189-218. doi:10.1016/S0040-1951(00)00046-9

Parke, J.R., White, R.S., McKenzie, D., Minshull, T.A., Bull, J., Kuscu, I., Görür, N., and Sengör, A.M.C., 2003. The Sea of Marmara: A two-dimensional seismic reflection data archive. Geochem. Geophys. Geosys., 4:1084. doi:10.1029/2002GC000493

Parsons, T., 2004. Recalculated probability of $\mathrm{M}>7$ earthquakes beneath the Sea of Marmara, Turkey. J. Geophys. Res., 109:B05304. doi:10.1029/2003JB002667

Polonia, A., Gasperini, L., Amorosi, A., Bonatti, E., Bortoluzzi, G., Çağatay, M.N., Capotondi, L., et al., 2004. Holocene slip rate of the North Anatolian Fault beneath the Sea of Marmara. Earth Planet. Sci. Lett., 227:411-426.

Rangin, C., Demirbag, E., Imren, C., Crusson, A., Normand, A., Le Drezen, E., and Le Bot, A., 2001. Marine Atlas of the Sea of Marmara (Turkey), Ifremer.

Reilinger, R., McClusky, S., Paradissis, D., Ergintav, S., and Vernant, P., 2010. Geodetic constraints on the tectonic evolution of the Aegean region and strain accumulation along the Hellenic subduction zone. Tectonophysics, 488:22-30. doi:10.1016/j.tecto.2009.05.027

Seeber, L., Cormier, M.-H., McHugh, C.M.G., Emre, Ö., Polonia, A., and Sorlien, C.C., 2006. Subsidence and sedimentation at a transform bend: The Çinarcik Basin and the North Anatolian Fault in the Marmara Sea, Turkey. Geology, 34(11):933-936.

Seeber, L., Emre, Ö., Cormier, M.-H., Sorlien, C.C., McHugh, C.M.G., Polonia, A., and Scientific Team of Marmara, 2004. Uplift and subsidence from oblique slip: The Ganos-Marmara Bend of the North Anatolian Transform, Western Turkey. Tectonophysics, 391:239-258. doi:10.1016/j.tecto.2004.07.015

Shillington, D.J., Seeber, L., Sorlien, C.C., Steckler, M.S., Kurt, H., Dondurur, D., Çifç, G., et al., in press. Slow-motion collapse on the flanks of the Sea of Marmara transform basins. Geology.

Sorlien, C.C., Akhun, S.D., Seeber, L., Steckler, M., Shillington, D., Kurt, H., Çifçi, G., et al., 2012. Uniform basin growth over the last $500 \mathrm{ka}$, North Anatolian Fault, Marmara Sea, Turkey. Tectonophysics, 518-521:1-16. doi: 10.1016/j.tecto. 2011.10.006
Steckler, M.S., Cifci, G., Demirbag, E., Akhun, S.D., Buyukasik, E., Cevatoglu, M., Coskun, S., et al., 2008. High resolution multichannel imaging of basin growth along a continental transform: The Marmara Sea along the North Anatolian Fault in NW Turkey. Eos Trans. AGU, 89(53):T21A-1921.

Tryon, M.D., Henry, P., Çağatay, M.N., Zitter, T.A.C., Géli, L., Gasperini, L., Burnard, P., Bourlange, S., and Grall, C., 2010. Pore fluid chemistry of the North Anatolian Fault Zone in the Sea of Marmara: A diversity of sources and processes. Geochem. Geophys. Geosys., 11:Q0AD03. doi:10.1029/2010GC003177

Zitter, T.A.C., Henry, P., Aloisi, G., Delaygue, G., Çağatay, M.N., Mercier de Lepinay, B., Al-Samir, M., et al., 2008. Cold seeps along the main Marmara fault in the Sea of Marmara (Turkey). Deep Sea Research Part I, 55:552-570.

\section{Authors}

Cecilia M.G. McHugh, School of Earth and Environmental Sciences, Queens College, City University of New York, 65-30 Kissena Boulevard, Flushing, NY 11367, U.S.A., e-mail: cmchugh@qc.cuny.edu.

Leonardo Seeber, Lamont-Doherty Earth Observatory of Columbia University, Route 9W, Palisades, NY 10964, U.S.A., e-mail: nano@1deo.columbia.edu.

M. Namik Çağatay, Geology Department, Istanbul Technical University, Ayazaga 80626, Istanbul, Turkey, e-mail: cagatay@itu.edu.tr.

Pierre Henry, Centre National de la Recherche Scientifique (CNRS), College de France, Bat Trocadero, Europole de l'Arbois, BP80, 13545 Aix en Provence Cedex 04, France, e-mail: henry@cerege.fr.

Christopher Sorlien, Earth Research Institute, 6832 Ellison Hall, University of California, Santa Barbara, CA 931063060, U.S.A., e-mail: sorlien@eri.ucsb.edu.

Michael Steckler, Lamont-Doherty Earth Observatory of Columbia University, Route 9W, Palisades, NY 10964, U.S.A., e-mail: steckler@ldeo.columbia.edu.

Gülsen Uçarkuş, Geology Department, Istanbul Technical University, Ayazaga 80626, Istanbul, Turkey, e-mail: gulsen. ucarkus@gmail.com.

\section{Related Web Links}

http://www.emcol.itu.edu.tr/Icerik.aspx?sid=9300 http://www.ldeo.columbia.edu/TAMAM/

http://cdf.u-3mrs.fr/ henry/marmara 